\title{
A picture of time and knowledge in the almanacs from Amazonas (1870 to 1927)
}

\author{
Rômulo do Nascimento Pereira, \\ Washington Dias Lessa, \\ Ligia Maria Sampaio de Medeiros
}

\section{TO THE READER}

This article proposes the registration and organization of data with regards to the Amazonian almanacs and is related to a broader research that focuses on printed artifacts from this location, from 1851 to 1930. This paper comprises the collection of editorial information and graphs as well as other observations arised from the reading on the almanacs. These publications were printed with types, rules, typographic vignettes, illustrations, photographs, varied styles organized according to the society's demand for specialized professionals to be produced following the available techniques and materials, especially the typography.

The set of data collected from the study of these publications provides a perspective on the development of the graphic activity circuit and its culture. In which it is believed to perceive a greater specialization of printed communication and the broadening of the domain of commercial information over others. In this sense a higher complexity is noted of the graphic design, of the visual rhetoric presenting advertisement and text, besides the more extensive use of the image as concrete evidence of this movement. It was also observed that this set of communication artifacts was also compared to a portrait or representation of society from which varied information was raised, and, to a certain extent, to life.

The objective of collecting these objects, which are not yet altogether observed, was twofold. First, to gather and register a particular type of printed artifact published in Amazonas as the subject - the almanacs. At the same time, aiming to organize and study graphic and editorial features of them, not as an isolated technical product, but as a social tool in which there are yearning, disputes, representations and more. There was also an effort to restore and organize information of interest to a wide number of specialists of the region and of the printed artifact. In order to do so, it was necessary the support of primary sources collected in the archives of the libraries of the Amazonian Museum, the Reunidos Cultural Center, the Public Library of the State of Amazonas, including the Digital Collection Management, all located in Manaus. In Rio de Janeiro, the library 
of the Brazilian Historic and Geographic Institute - IHGB, the initials in Portuguese - was consulted as well as the digital collections of the Brazilian National Library and the Brasiliana Library of the University of São Paulo. Research was also conducted in other databases of national and international universities and of other foreign organizations.

The adopted temporary clippings begin with the introduction of the printing technology in Amazonas, occurred in 1851, going through 1930, and during this period 17 almanacs were identified. Of the total, two referred to the Madeira River region, seven are complimentary almanacs, which were distributed at no charge to clients of a printed office, two pharmacies and a store, one of the almanacs covers the Police Force of Amazonas. Therefore, they possess a wide range of information, making use of distinct graphic, editorial and productive resources and forming a heterogeneous collection of printings. At least eleven were designed and printed by typographic offices in Manaus, two were produced in Europe, and in three others it was impossible to specify the place of their production.

There is large discontinuity in the almanacs' publications (Figure 1), and it was noticed a greater occurrence of these printings, with nine editions during the period of wealth in the region, known as the Amazon Rubber Boom, from 1890 to 1910 . Out of this set of seventeen, eleven were completely analyzed, whether in digital or physical form. Indeed, they are the objects of study used herein. Of the other five almanacs, the access was by some pages found in the Internet and other digital written references. Annuals and other prints lacking precise indications were not included, as observed in the "Prologo" of the 1889 Almanach Madeirense. In this prologue, the editor mentions the difficulties and critics received whilst organizing the first almanac in the Madeira River region, that was published in 1888 , of which another reference was published in a newspaper. From this almanac, there are imprecise records of possible issues of 1891, 1892, and 1893, to be confirmed. Just as in the 1907 Almanach Camillo, which in its cover page indicates "V Anno", possibly four other previous editions were published, although not yet found.

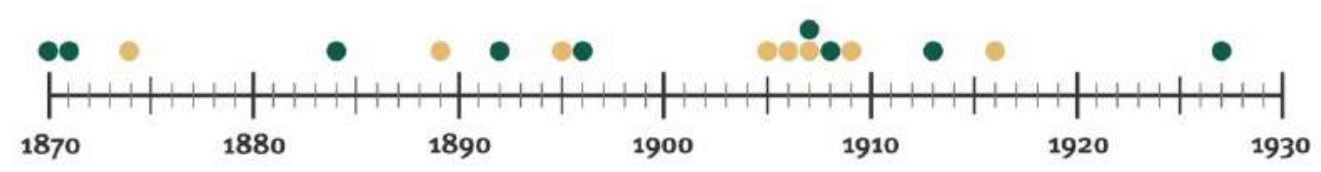

Figure 1: Year distribution of the 17 identified almanacs. The color variation refers to the almanac's frequency of publication, two equal tones in sequence indicates issues consecutively organized by the same publisher (Own source). 
The Brazilian bibliography on the subject did not reference the almanacs related to Amazonas or even the northern region of Brazil. As a matter of fact, the first two, of 1870 and 1871, seem to have been completely ignored until today, as no records of them were found in the works consulted nor in other sources. In research conducted by Fernanda Martins (2017) on printed material of Pará consists of a set of almanacs published in that location. A gap that begins to close with research about the region's printed culture, although this paper does not intend to exhaust the topic. Its goal is to contribute to the access and the broader circulation of these popular and significative information tools. Not just as a data depot on the past, but as a picture or snapshot of several narratives registered on paper, images, design, production, speeches and in representation of a community, including what has not been registered. And it is worth remembering that almanacs are still produced in this day and age, surviving by publishing a combination of short, fragmented, and sometimes just curious or anecdotal information.

\section{ALMANAC CULTURE}

Almanack, almanach, almanak and the current spelling in Portuguese almanaque, are the titles that originally identify the annual publication that contains diverse information, including a calendar with festivities, relevant material of local interests, advice, and more. This work is related to two areas: time and knowledge, organized according to the demands of each place and time. Correia and Guerreiro (1986, p. 44) consider the almanac as a way imported from some asian courts. Within them, astrologers presented to their sovereigns loads of information, including indications of the stars at the beginning of each year. The calendar is also present in Europe, printed on woodcut in the 15th century in patterns, some of them decorated. It is no accident that this form of arranging time in an annual calendar makes it an essential part of this publication. They have varying sizes and page numbers, although portable editions seem to be more common, easier to check. They were produced handwritten in the Middle Ages and gained popularity with the arrival of printing in the 15th century.

The Almanach Perpetuum, incunabulum by Abraão Zacuto, was the first one of its kind published in Portugal, in 1496, and brings a collection of astronomical information arranged in tables. This information was important to the Age of Exploration, and to a Portuguese expedition that aimed to dock in the Indies, but docks at a coastal place with a great deal of Brazilwood at the threshold of the 16th century. This land gave birth to the Brazilian colony, territory where typographic technology has remained forbidden by royal decree for a long time. Its introduction occurred in 1747 by a Portuguese man known as António Isidoro da Fonseca, although his publishing adventure was interrupted and he had to return to Lisbon. It was only when the Portuguese court, escorted by English Navy 
ships, escaped from Napoleon's troops that the first printing office could be definitely established in Rio de Janeiro in 1808.

In 1811, the installation of the second printing office is established in Bahia, owned by Manoel Antonio de Silva Serva. The following year this printing office became the first privately owned establishment in Brazilian territory, and published Almanach para a cidade da Bahia 1812 [Almanac for the city of Bahia 1812]. Still in the 19th century, other almanacs are printed and become popular, like Almanak Laemmert, published in Rio de Janeiro. In 1820, there are records indicating the appearance of the first printing office of Grão-Pará, but it was only with the boost of Amazonas to a provincial town that this location can benefit from the services of Manoel da Silva Ramos' printing office, in 1851. The first identifiable Amazonas almanac was published 19 years after the beginning of printing activity, in 1870. This sort of publication was defined in the book Os sucessores de Zacuto [The successors of Zacuto]:

An almanac is a guide, an instrument that contains elements for the organization of everyday life. First of all, it manages time based on a yearly calendar. Organizes activities, arranging useful information for these activities. Organizes the community by registering proverbial moral and culture. Organizes space by providing a clear picture of the universe, traditionally defined in astrology. Without losing the original meaning of enumeration, the notion of almanac will tend to reflect the idea of compilation of knowledge, in particular intended for audiences with little access to other readings. (Galvão, 2002, p. 11).

Usually characterized as being a periodic publication, the almanac would thus have a life more ephemeral than a book, whether for being handled in excess or for being discarded after the launching of following issues. Nonetheless, this publication will be the only edition for many families, being kept as a source of knowledge. Le Goff (1990, p. 527) speaks of the calendar as a system associated with the almanac, both analyzed as cultural objects, "a privileged place where popular and erudite cultures meet." In France, almanacs were associated to famous characters and official discourse, but also raised a lot of questions and criticism. During the French Revolution, they were extensively used as propaganda (Andries, 1996, p. 294). This was when they became objects of government censorship and academic criticism for being regarded as a means of disseminating futility (Lisboa, 2002, p. 16). In Brazilian context, they are artifacts equipped with social importance, or, as preferred by Ferreira (2001, p. 20), it speaks of their "civilizing aspect" by bringing varied knowledge to distant places, transitioning between rural and urban areas, and through different social classes with poise. 
In the almanacs, communication may be thought of in terms that Flusser (2007, p. 93) puts it, as the accumulation of acquired data to make sense. Thereby the political and social structures of a location, in multiple signs, would be visible and organized for a traveler. Similarly, they sought to arrange the time by giving social meaning to this elastic measure, indicating, for instance, the sign of the month, saint's day, holidays, phases of the moon or other information of which the reader wanted to write down. Afterwards it will constitute a repository of several curious pieces of information and advice, again as propaganda. Within the Brazilian editorial outlook in the 19th century, the almanac occupies a privileged position and there are reasons for being sponsored by local government, because their production provided an indicative trait of growth and served as a means for dissemination.

The commercial information, in the form of indication of commercial firms, self-employed professionals, and advertisements, are also present in this type of publication. And as noted, regarding this collection from Amazonas, this information stands out in complimentary almanacs given to clients by firms and in almanacs with strong visual and rhetorical appeal such as that of 1912-13. In Brazil there is an increasing popularity in so-called pharmacy almanacs, especially in the beginning of the 20th century. In Amazonas only two of these were found, published in 1907 and 1908. Albeit in the January 11, 1910 edition of Correio do Norte there was a note appreciating the receiving of Almanack da Pharmacia Amazonas [Amazonas Pharmacy Almanac], this would be the forth published.

The following survey and the study of the almanacs from Amazonas almanacs allows for the observation of local graphical circuit, beyond the data shown related to quantity of active professionals and companies. By peeking at their pages, it is aimed to read their resources, graphic styles, images, text, projects, and from them observe the formation of editorial and graphical activity and its relation to society. Even though the collected almanacs are from inconstant and distinct periods, this diversity and contrast only makes the perspective brought by these publications richer and more interesting.

\section{AMAZONAS ALMANACS}

The seventeen identified almanacs were organized in a table for registration purposes, of these eleven were effectively consulted and some were considered more significant according to their project, graphical and visual features, data organization and symbolic importance. Therefore, the almanacs of 1870, 1884, 1895, 1905 and 1913 had more detailed descriptions of their editorial and graphic information, while the others had been mentioned only when deemed conve- 
nient to this narrative. Data of interest were also removed, like indications of professionals and trading houses in graphic arts circuit, with additional observations, some of which were gathered by research in journals which were considered relevant to form an objectively condensed overview.

\begin{tabular}{|l|l|l|l|}
\hline & Títle & Year & Printing [location and house] \\
\hline 1 & $\begin{array}{l}\text { Almanack Administrativo } \\
\text { e Commercial do Correio } \\
\text { de Manáos da Província do } \\
\text { Amazonas }\end{array}$ & 1870 & Manaus, Typ. do Correio de Manáos \\
\hline 2 & $\begin{array}{l}\text { Almanack Administrativo } \\
\text { e Commercial do Correio } \\
\text { de Manáos da Província do } \\
\text { Amazonas }\end{array}$ & 1871 & $\begin{array}{l}\text { Manaus, Typ. do Commercio do } \\
\text { Amazonas [Edited by Correio de } \\
\text { Manáos] }\end{array}$ \\
\hline 3 & $\begin{array}{l}\text { Almanack Administrativo da } \\
\text { Provincia do Amasonas para o } \\
\text { anno de 1874 }\end{array}$ & 1874 & $\begin{array}{l}\text { Manaus, Typ. do Commercio do } \\
\text { Amazonas }\end{array}$ \\
\hline 4 & $\begin{array}{l}\text { Almanach Administrativo } \\
\text { histórico Estatístico e Mercantil } \\
\text { da Provincia do Amazonas }\end{array}$ & 1884 & Manaus, Typ. do Amazonas \\
\hline 5 & $\begin{array}{l}\text { Almanach Madeirense para o } \\
\text { anno 1889 }\end{array}$ & 1889 & $\begin{array}{l}\text { Porto (Portugal), Typ. de Arthur José } \\
\text { de Souza and Irmão }\end{array}$ \\
\hline 6 & $\begin{array}{l}\text { Almanach Madeirense para o } \\
\text { anno 1892* }\end{array}$ & 1892 & - \\
\hline 7 & $\begin{array}{l}\text { Almanach do Amazonas } \\
\text { Histórico, administrativo, } \\
\text { commercial, estatistico e } \\
\text { literário }\end{array}$ & 1895 & Manaus, Typ. do Amazonas \\
\hline 8 & $\begin{array}{l}\text { Almanach do Amazonas } \\
\text { Histórico, administrativo, } \\
\text { commercial, estatistico e } \\
\text { literário }\end{array}$ & 1896 & Manaus, Officinas do Diario Official \\
\hline 9 & Almanack brinde Palais Royal & 1905 & Manaus, Palais Royal \\
\hline 10 & Almanack brinde Palais Royal & 1906 & Manaus, Palais Royal \\
\hline 11 & Almanack brinde Palais Royal* & 1907 & Manaus, Palais Royal \\
\hline 12 & Almanach Camillo & 1907 & - \\
\hline 13 & $\begin{array}{l}\text { Almanack da Pharmacia } \\
\text { Amazonas* }\end{array}$ & 1908 & - \\
\hline 14 & Almanack brinde Palais Royal* & 1909 & Manaus, Palais Royal \\
\hline
\end{tabular}




\begin{tabular}{|l|l|l|l|}
\hline & Títle & Year & Printing [location and house] \\
\hline 15 & $\begin{array}{l}\text { Almanak Amazonense de 1912- } \\
1913\end{array}$ & 1913 & $\begin{array}{l}\text { Paris (França), Société Générale } \\
\text { D'impression. Edition by Empresa do } \\
\text { Almanaque Henault (Rio de Janeiro) }\end{array}$ \\
\hline 16 & Almanack Amazonense Paulo & 1916 & No indication \\
\hline 17 & $\begin{array}{l}\text { Almanack da força policial do } \\
\text { Estado do Amazonas* }\end{array}$ & 1927 & Manaus, Typ. da Imprensa Pública \\
\hline
\end{tabular}

Table 1: Amazonas almanacs, those with an asterisk after the title have been partially consulted.

In 1870 the Almanack Administrativo e Commercial do Correio de Manáos da Província do Amazonas [Administrative and commercial almanac of the Correio de Manáos of the Province of Amazonas] was organized by the editor Eugenio Ataliba dos Santos Ferreira (Figure 2). He comments in the text entitled "To the reader", which opens the edition, the "notable missing feeling" that an almanac makes to both national and foreign visitors arriving to the province capital. The editor remarks on his audience: "It is perfectly understandable the gaps within an assignment like this, all the more when it is not developed in the Province the taste for this and other works." Implying that the audience had still many limitations.

Its edition has small dimensions, about $10 \times 14 \mathrm{~cm}$, and 240 pages. It begins with a calendar in which each month was composed in several pages, with a typographic vignette of the zodiac sign corresponding to the month and varied information. The content is divided into four parts: the first with the names of the Imperial Family, ministers, senators and deputies. The second, with the political, administrative, judicial, police organizations and other information about the Province of Amazonas. There were also the department titles, positions and the names of the occupants, both in the capital and in districts in the countryside. The third contains commercial and ecclesiastical information, and the fourth lists the names of retired employees and a few advertisements.

This almanac registers five "Typographias" [printing offices] having the name of five journals also listed in the same publication: Correio de Manáos, which published this almanac; Amazonas; Commercio do Amazonas; Catechista, Reforma Liberal. In the newspaper Correio de Manáos of September 7th, 1869, there is an advertisement of the almanac's editor asking all merchants, laborers and workers to provide information about their activity to be included in the Almanak's edition: "the first that will have the province." In the same newspaper, in the October 11th, 1869 edition, there is a note indicating that the almanac was in the press, that it would be distributed by December 15th and that advertise- 
ment would be accepted until the end of November. From this data, it is possible to have an idea of the steps and production time of this publication, asking information as well as professional and commercial indications in September, the following month stating that the almanac is in printing process, but still accepting advertisements. And finally announcing that the almanac would be finished by mid-December.

The following year, the almanac of 1871 is published by the same printing office. In this year there were only four printing offices registered. In the publication's opening text the editor promises "to improve this paper that, still incomplete for the difficulty of finding data and clarification, deserves to be forgiven." Both almanacs are graphically modest, joining them in the publication of 1874 with similar features and organization (Figure 2), although having a more common and unconventional graphic design. These three almanacs mark the beginning of this type of publication in Amazonas.

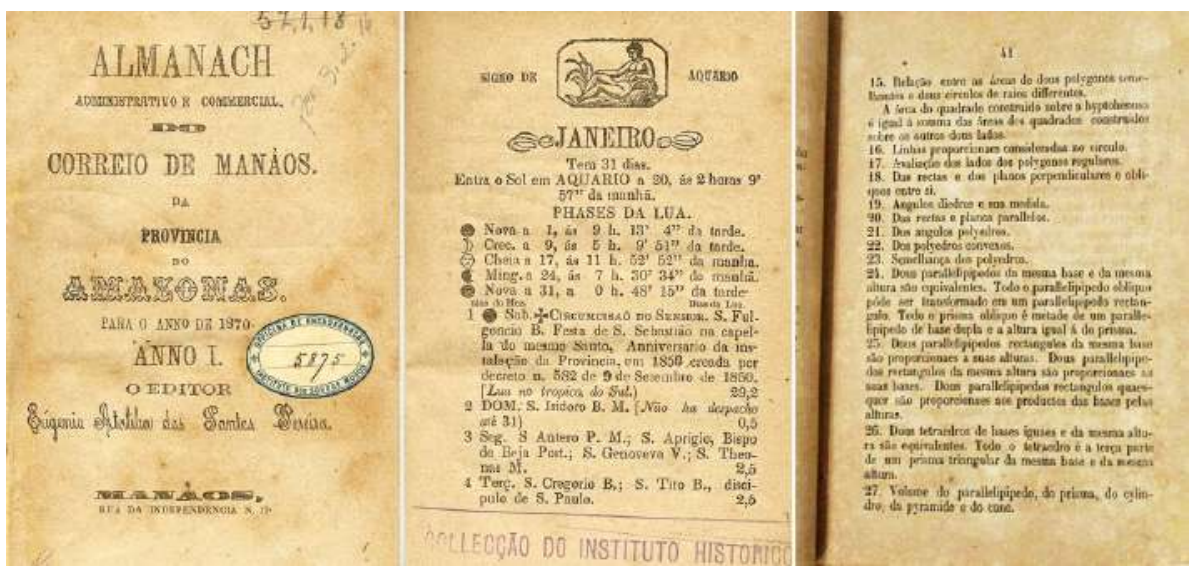

Figure 2: Almanach of 1870's cover page with title composed in a centralized form in various types and styles. Around the center of the same almanac's calendar page, in which is the use of typographic vignettes. On the left, detailed page of the third almanac of 1874 (used with permission of IHGB and the Amazonian Museum, respectively).

The Almanach administrativo histórico estatistico e mercantil da Provincia do Amazonas para o anno de 1884 [Administrative, historical, statistical and commercial almanac of the Province of Amazonas for the year of 1884] was the fourth to be published, ten years after the preceding. It brings already a significant change in relation to its predecessors, because it has in its title page a picture covering the whole page (Figure 3). On this page, there is a large river with vegetation, dwellings, human elements and vessels, a canoe can be seen from top to 
bottom, followed by a sailboat, after a steam boat and, in a prominent position, a ship sailing in front of the sun, which seems to rise and extend its brightness across the upper part of the picture. This figurative image reflects the signs of growing prosperity and the belief of a brilliant future. These are some of the signs of this movement or progress: in 1867 the navigation on the Amazonas River was permitted to foreign vessels. In 1878, the Cathedral in honor of Our Lady of Immaculate Conception was inaugurated, according to Mesquita (2006, p. 67), being "the first great architectural work built in Manaus." In the subsequent years, other buildings were built, businesses were opened, the population and formal education were magnified. In accordance with Santos (1980, p. 76), by the end of the 1870s, the rubber exploitation had become the main source of wealth in Amazon, beginning the period of great wealth provoked by the latex exploitation, which becomes intensive by the end of the century. The shiny or bright future seemed to be the fate of the great Amazonas, as the picture in the title page seemed to express.
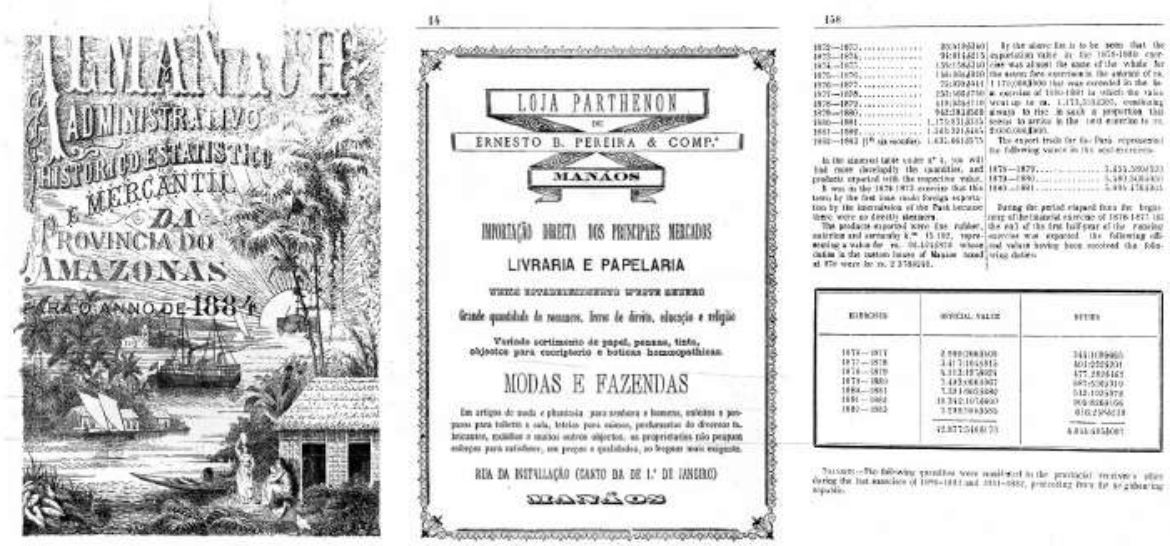

Figure 3: Illustrative front page, full page advertisement on Loja Parthenon, and "Parte Mercantil" [Commercial Section] page, formed by two columns, with rules and tables (used with permission of the Brazilian National Library).

In its editorial entitled "To the readers," it states that the publication of an almanac was established as an "imperative need before the upward movement that the same province experiences in its fast and safe progress." It points out, in the same text, that its edition was only possible due to the capital allocated by the Assembleia Provincial [Provincial Legislative Assembly]. Which explains, to some extent, the excessive patriotism when intended to "engage in propaganda of the large resources this vast region has, for the most part unknown and, what is more painful to say, within the country." After these explanations for the first part of 
the almanac, called "Preliminares" [Preliminaries], is the "Folhinha, Informações Uteis e Genealogia da Augustissima Casa Imperial" [Flyer, Useful Information and Genealogy of the Magnificent Imperial House].

Each of the twelve months of the flyer was organized in only odd number pages, with the days of each month formed by two columns. There are indications of the Zodiac sign, the phases of the moon, and the saints of the day. In the even number pages, there are advertisements in full page or up to two on the same space. One of the full-page advertisements is of Typographia do Amazonas, the same one that prints this almanac. In addition to offering printing services for "excessively low prices," it claims to possess three presses of the builders Maulde Geibel and Wibart, "Liberty" by F. M. Weilers and "Perola" by Goloing and Comp. In other advertisement, there was a "Officina de Encadernador" [Bookbinder Office], led by Virgilio J.C. Travessa and located in the already mentioned Typografia do Amazonas. This first set of advertisement used rules, borders, capitulates, various types and other graphic elements that build a wide variety of graphic, visual and rhetorical compositions.

The almanacs' second section is the "Parte Administrativa" [Administrative], followed by the "Parte Histórica" [Historical], the fourth is the "Parte Estatística" [Statistical] and in addition to the textual part organized in two columns, is composed of several tables, sometimes incorporated to the layout, other times covering full and double pages. The fifth and last section is the "Parte Mercantil" [Commercial], which in turn is organized into four subsections, the first one would have information translated into English and French. This is the longest part in the almanac, with some more advertisements on its last pages.

This almanac registers on its page the presence of three bookbinders, a bookstore, four journals: Amazonas, Commercio do Amazonas, Jornal do Amazonas and Rio Madeira, located in the inner-province town of Manicoré. It also registers a "photographo" [photographer], three "typographias" [printing offices] and twenty-one "typographos". ${ }^{1}$ Undoubtedly the number of printing offices and other professionals in the graphic field in Manaus was greater than registered in the almanac, that depended on forwarding information from businesses and professionals.

In the January 27, 1884 edition of Amazonas, it is announced that the almanac is on the press and is accepting advertisements, just by heading to the printing office. The same announcement is repeated from time to time, until at least the

1 It is important to note that the term "typographos" seems to indicate both the professionals who plan and compose the printed matter and those responsible for the impressions because at the time these activities were often performed by a single individual. 
March 7, 1884 edition, which indicates a delay in the production and that the advertisements were the last to be printed. However, this graphic artifact was well edited, planned and produced with good command of the techniques, holding a more complex visual language than the previous ones. It consists of a large volume of information, some translated into two other languages, and uses composition of tables. It is noticeable a better command of statistical and commercial information.

In 1889 the Almanach Madeirense was published, alluding to the region of the Madeira River, in the countryside of Amazonas. This publication highlights the interest of a region to be noticed, having the community information arranged in one publication. It is also a sign of prosperity, as this edition, although organized by Amazonas' locals, was printed in the city of Porto, in Portugal.

The Almanach do Amazonas Histórico, administrativo, commercial, estatistico e literário de 1895 [Almanac of historical, administrative, commercial, statistical and literary Amazonas of 1895] was organized by the alumnus José Feliciano Augusto d'Athayde and Arthur Cardoso de Oliveira, and holds a long list of collaborators (Figure 4). In the brief opening text, they speak of the literary part, which "is extremely useful, especially to the beautiful sex," in a clear reference to the feminine readers of the publication. This section was non-existent in the six previous almanacs that were analysed before, information thoroughly highlighted in its title. The contents begin with a general calendar with varied indications, followed by another monthly calendar, set in two columns on a single odd page number. On the pages with even numbers, there are a great number of advertisements with multiple arrangements and extensive use of typographic vignettes, rules and other graphic and visual resources. Next there is a part dedicated to Brazil. The third part covers Amazonas with a list of departments, positions and names, including the Imprensa Official [Brazilian Official Press], inaugurated in 1893. This institution started to publish the Diario Official [Official Gazette], and in this almanac there is information that shortly will be built a lithographic office. Whilst describing the Brazilian Institute of Arts and Craft, there is a indication of a post in "Drawing with applications to the Arts. Sculpture." and, in the professional course, it is cited a "Bookbinding workshop."

The fourth part is entitled "Commerce, Industry and Professions" and registers three journals from the capital: Amazonas, Diario Official and A Republica, and four from the countryside: Humaythá, in the Madeira River; Labrense and Rio Purus, in Lábrea and Município in Itacoatiara. Four other bookstores, one bookbinding office, two photography shops and five printing offices: Amazonas, Imprensa Official, Lino Aguiar, República, Silva and Gomes. And 38 printers registered in three offices of the capital's newspapers. The almanacs were sold in bookstores, other stores and in their own printing offices. The almanac of 1895 
had several advertisements published in January in the Diario Official announcing its sale in the Clássica, Universal bookstores and in the store D. Pedro II.

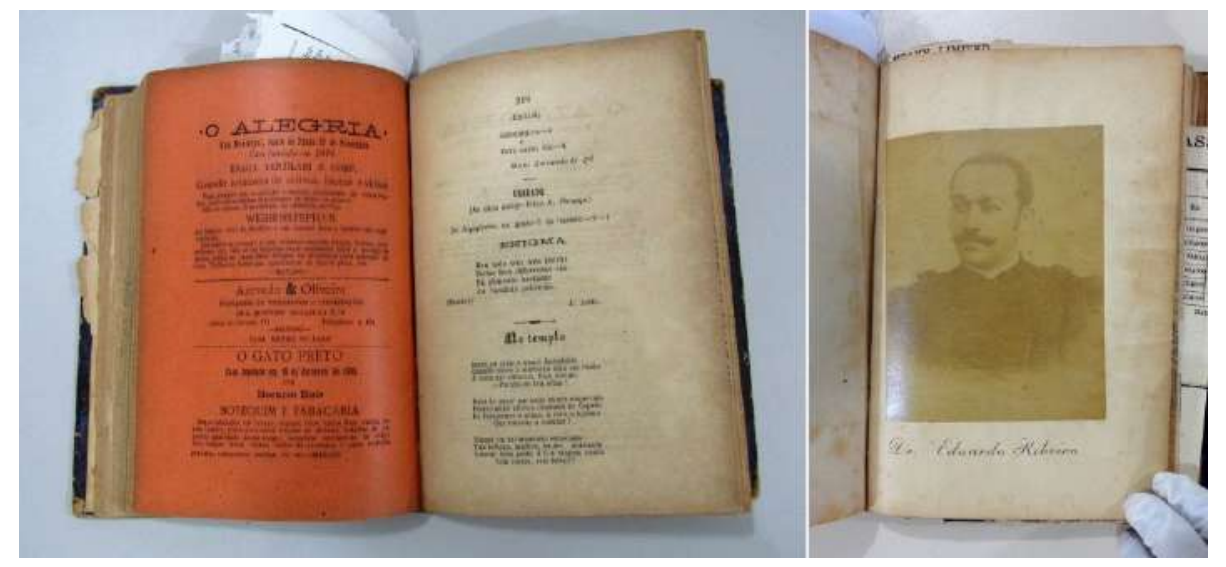

Figure 4: Double page of the almanac of 1895, and photograph of the Governor of Amazonas Eduardo Ribeiro published in the almanac of 1896 (with permission of the Amazonian Museum).

In a note in the October 27, 1895 edition of Diario Official, speaks of the next almanac to be published, says the editor that all "useful information" will be accepted until November 20th and that the following edition will have"developed historical news containing the biography of the most prominent men of the State and more: commercial, administrative, statistical, literary news, etc." It is also said that advertisements are accepted from shipping companies, businesses and self-employed professionals, showing the prices of full-page advertisements "entitled to a free copy", and prices of half-page or quarter-page advertisements, indicating where the interested party should go. The almanac of 1896 is organized by Augusto Celso de Menezes and presents a single photograph of the Governor of Amazonas, Eduardo Ribeiro (Figure 4), as presented on the cover page. There features a literary section, like the previous almanac, and a varied number of advertisements, including the presence of colorful papers.

At the beginning of the 20th century, four almanacs were identified as having produced a "bookstore, stationery store, steam printing office and bookbinding office," this is the Almanack brinde da Livraria Palais Royal [Complimentary almanac of Livraria Palais Royal]. The issues were produced in hardback cover for 1905, 1906, 1907 and 1909, and were distributed free of charge. The owner was Lino Aguiar, and his company was the Amazonas main graphic enterprise during this period. The almanacs were more than just a simple gift to the clients. They are, to a great extent, a showcase of the services and a sophisticated adver- 
tising piece to be consulted all year round. Its French name alludes to the luxury and cosmopolitan modernity of Paris, common practice to many stores and enterprises in the Province of Amazonas.

The content of the 1905 edition has a smooth humorous speech, different from the previous almanacs, more organized. As it is made clear in an introductory note by Tósca: "An almanac, although complimentary, not judging the year, is like a suit lacking a piece of clothing. And to judge it is essential to have years of experience in judging. And, regarding this gift, I am honestly up the creep." It is a resource to gain the compassion of your audience and make the reading effortless, always having own advertisements sprinkled with information and funny stories.

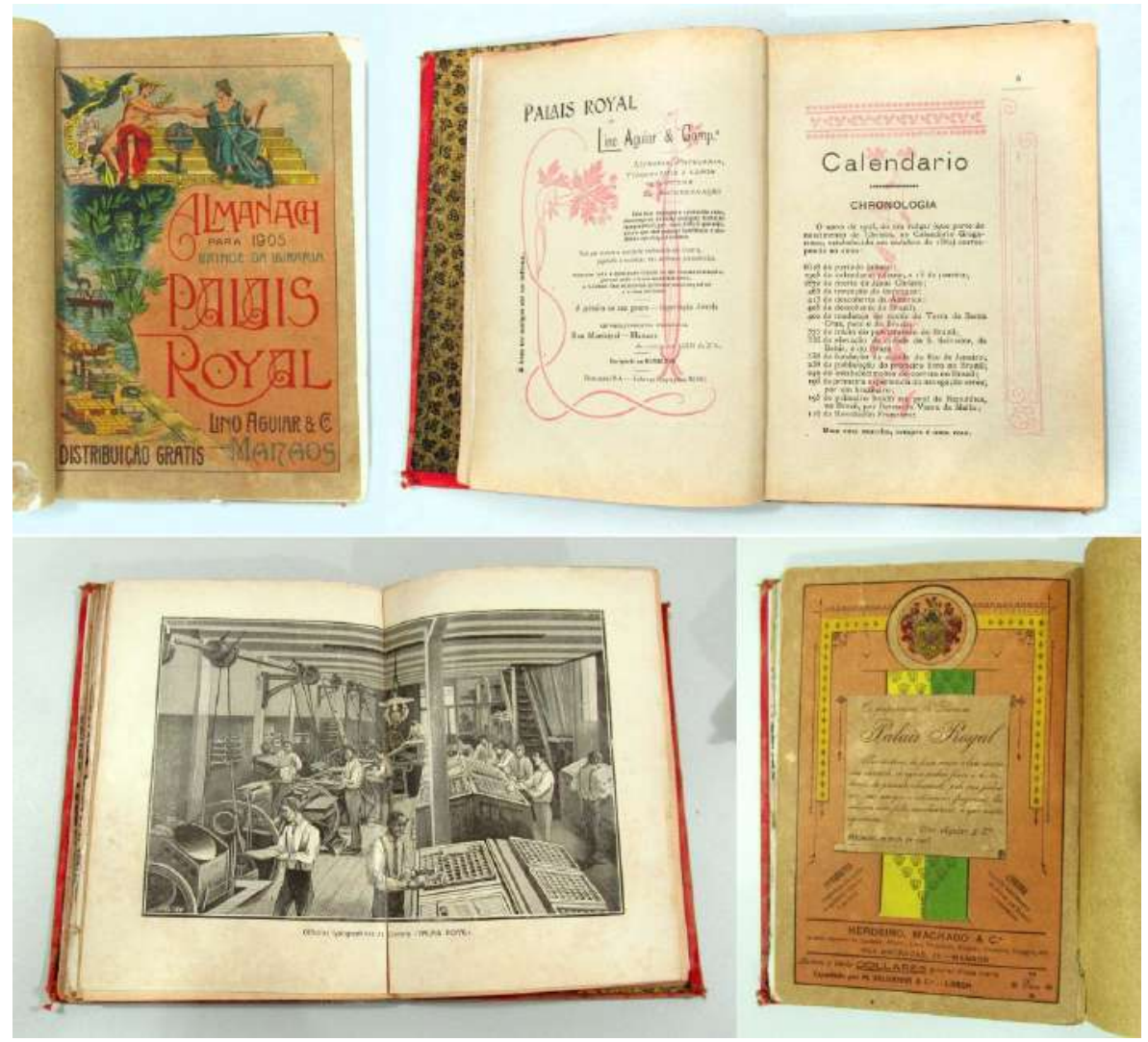

Figure 5: Livraria Palais Royal complimentary almanac of 1905: cover page, double pages illustrated with Art Noveau vignettes, with image representing the interior its printing office and colophon (used with the permission of the Amazonian Museum). 
Though this unpretentious tone, these complimentary almanacs are well polished pieces of a business strategy from a graphic company, with the most visible piece being the Palais Royal bookstore. The two first issues, completely analyzed, have the traditional calendar, with a variety of historical information, with a more general nature and vast literary or recreational content. There are several advertisements, mainly related to Palais Royal, sometimes highlighting its graphic or bookbinding services, its great variety of books, along with the advertisements of other businesses. A great amount of images are used, either photographic, clichés, vignettes, and other varied types, borders, rules, bound in hardcover. The 1905 edition advertises a colorful cover and the core printing in two colors, always black and another color, in a large stockpile of Art Nouveau vignettes (Figure 5).

The following year the almanac's pages remove the colors giving place to many humoristic drawings. There are only the credits for produced images, including the printmaker. It continues to be produced in 1907 and 1909, in the latter being announced: "This office has just been renovated with modern and varied German equipment, and with improved machinery, in order to satisfy the due execution of all services." On behalf of the Jornal do Commercio of March 25, 1907, the then almanac is described as being "this magnificent publication... warehouse of accurate information about the State of Amazonas in general and on commercial matters." The newspaper also highlights the literary and recreational part and praises the excellent text and great work.

The Almanak Amazonense de 1912-13 presents considerable differences to the previous almanacs, including the fact that this publication was edited by the company Henault in Rio de Janeiro, with plentiful and rich illustrative material. The fact that the almanac was edited by a printing office in another state and printed in another country was not innovative, because a numerous amount of iconographic albums were produced by the state government at the end of the 19 th century and beginning of the 20th. Henault, as advertised in the almanac, was a representative of foreign manufactures, working especially with drugs, perfume, dyes, fashion items and new products. In the same advertisement, it is said that there is an "advertising section" responsible for publishing in Almanak Brasileiro Commercial Ilustrado [Brazilian Commercial Illustrated Almanac] and in Almanak Médico-pharmaceutico do Brasil [Medical and Pharmaceutical Almanac of Brazil].

This almanac starts with a 1912-13 calendar, each formed of only a couple of pages, followed by pictures of works of art, building views, mostly foreign, some national figures and varied information. This first part of generalities was printed in ochre coated paper, which does not occur in the following section, entitled "State of Amazonas," printed in black uncoated paper. This section has 
information regarding the federal and state departments and the city government, followed by the "General index for occupations in Amazonas." After that there is big advertising section, and this seems to be the artifact's main objective - to represent the ostentatious wealth of the Amazonas. Not just informing, but also illustrating a sophisticated and varied urban life, making vast use of the image, as in photographs and illustrations. Several European artists sign the drawings in the advertisements, including the Parisian artist Marcel Lebrum, responsible for many works published by Henault, in Rio de Janeiro. In those publications, there is a bourgeois lifestyle, giving emphasis to the female figure. There still are a great number of advertisements printed in one color, with pictures of the façade or the interior of businesses as the main element (Figure 6).

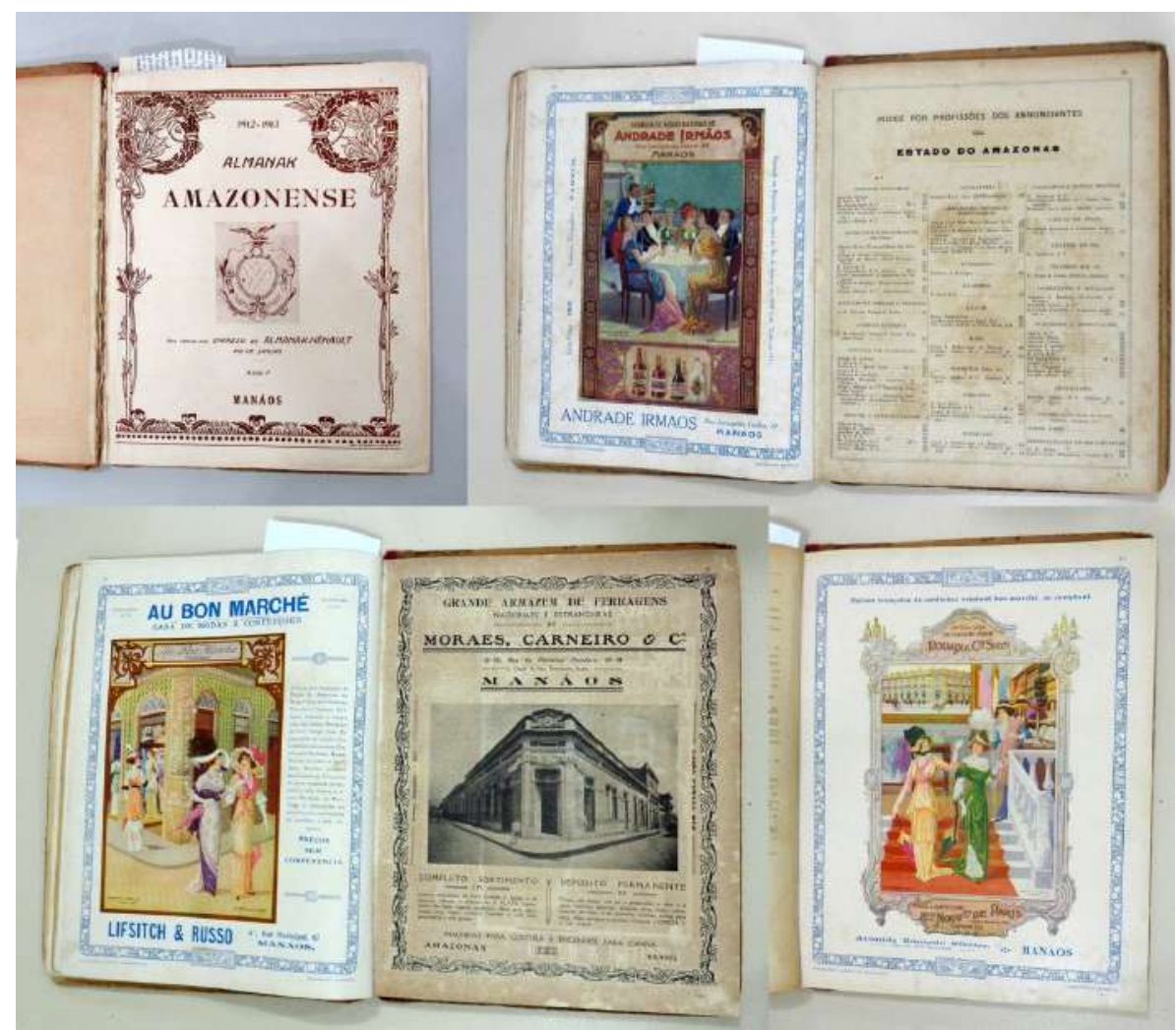

Figure 6: A 1913 almanac: cover sheet and double pages featuring the colorful advertisements produced and printed in Paris (used with permission of the Amazonian Museum).

In the part entitled "General index for occupations in Amazonas", in the section "Newspapers and Magazines", ten journals are indicated, nine "Book 
and stationery stores", quatro "Photography shops" and ten "printing offices." In the colophon contained on the last page, it is said that the publication was made in August, 1912 by Société Générale D'impression, with the collaboration of Arc Engraving Company in Paris, in engraving of the colorful pages. Its is also stated that the inks used for printing are manufactured by Casa Lorilleux e Companhia. The last identified almanacs, of 1916 and 1927, depict the end of the economic period and the misconception brought by the economy of the rubber boom, holding rather graphically and editorially modest pages.

To conclude this survey, an interesting text published in Correio do Norte on Tuesday, October 3rd, 1911, in a first-page column entitled "Cavaqueando" [Shooting the Breeze]. One can get a sense of receiving printed information, including the almanacs, as can be read a good-humored speech on the proliferation of existing publications and relationship between the text's author and the enigma:

We experience a full control of the practice of riddles. Our confused workbench is cluttered with almanacs from several nationalities; the thought harassed in pansophic diabolism to resolve the massive wave of devilish productions of all genres, the lost view of mare magnum of books and booklets, dictionaries, albums, auxiliary books... Anyway, all kinds of things.

I myself seem like an enigma very difficult to solve [...]

The reader might dislike this sort of fun and find it true that riddles shrink their brain and bewilder their rationale.

Right now, I don't know where I should turn my attention to, and I would betray my conscience if I intended to speak of another thing. My brain seems to want to devour itself at this moment [...]

I rest from the fatigue of an almanac in another.

My eagerness is to crack, crack riddles, and with this yearning, I would leaf through the Lembranças [Memories] when the simplicity of two initials caught my attention - S.C. Manaus. Amazonas. We are in the presence of a riddler from Manaus [...]

Interestingly, around page 358 of Senhoras [Ladies], they are also there. And I just had a very quick peak at this almanac.

Not all of them are cracked, yet, but may Mr. S.C. pray the De profundis, though I haven't so far found out the "only walks ahead" [...]

Yet, the author praises the riddler of Manaus, cites other important players, always enthusiastically, then end the words and sign: 
After this reading, the reader may feel at least somehow curious about plunging into tangled meanders of Oedipus' art, and run to any bookstore to buy all the almanacs, and, from this curiosity, it may arise an incurable riddle mania.

This is my most sincere wishes. Jodoval.

\section{FINAL CONSIDERATIONS}

Although there was a significant number of almanacs collected in Amazonas, while searching at local journals, other almanacs were cited, but there was no other evidence of their existence. For instance, in a note from the Jornal do Commercio of December 19, 1907, there is a warning towards advertisers of the Almanach Commercial do Amazonas that they could remove their copies starting on January 15th. In the same newspaper, the January 21, 1908 edition said that the almanac was offered to the newspaper editorial staff by Livraria Universal. There is also the Almanack da Empreza Telephonica do Estado do Amazonas, cited in the January 31, 1895 edition of Diario Official. It is believed that there is a large number of almanacs to be discovered and unraveled, including those registered herein, as it is just a first discussion on the topic.

In the set of registered information about Amazonas almanacs, the aim was to throw some light, with graphic and editorial hues, on an artifact, rich source of study, and not only focus on what was written and quantified on its pages. Its printed format, visual language and information arrangement are of the same importance. By reading them, it may be noticed a greater use of resources - graphic, visual, rhetorical - to grant distinction and value to what is informed or advertised. And to foster other readings of the time apart from the calendar on their pages. It was observed a diversification of information, a literary section is seen in the almanacs of 1895 and 1896. As well as, in the fourth almanac, there was a revealing movement: a perceptible reduction of pages, due to working time, the calendar, bigger space occupied by advertisements and statistical data. Along with the considerable occurrence of images, be in the form of either typographic vignettes, illustrations or photographs, mostly from 1896.

The Amazonas almanacs, initially a privileged source of political and administrative information, with time had their pages covered with literary and commercial information. Including professional recommendations and advertisements, until taking over the publication, turning it into a means for advertising of local businesses, clearly adopted in almanacs from the 20th century. Turning these publications into complimentary printings, like those carefully published by Livraria Palais Royal. The Frenchlike name of this business, including a print and bookbinding shop, can be read as an indication of the adoption of the French- 
-toned model of modernity. It was also observed in the advertisements finally drawn up by European artists in the almanac of 1912-13, duly printed in Paris.

Our incursion by the Amazonas almanacs showed various forms of organizing and viewing information. It is wished that the enthusiasm for the almanacs is renewed, as expressed by Jodoval, author of the previous citation. Although he sought to crack the almanacs' riddles, he hopes this printed material continues to be published, read, studied, and that they contribute to the reflection of time and social space in which they are inserted including the design. From this point, it was observed that the graphic smudge has become more complex by articulating text, image and varied messages, demanding a better technical command in the execution plan. Although there was no credit, in any of the analyzed publications, for the professionals responsible for the "art" or "artistic direction" in the almanacs, just their editors, printing offices, a few engravers or illustrators deserve, if anything, this acknowledgement. This is just one more fortuitous observation, like many others, that the almanacs, and not only them, nourish themselves.

\section{REFERENCES}

Andries, L. (1996). Almanaques revolucionando um gênero tradicional. A Revolução Impressa: A Imprensa na França 1775-1800. São Paulo: Edusp.

Buchanan, R. (2009). Thinking about design: an historical perspective. Philosophy of Technology and Engineering Sciences, 9. Elsevier.

Cardoso, R. (org.). (2005). O design brasileiro antes do design: aspectos da história gráfica, 1870-1960. São Paulo: Cosac Naify.

Correia, J. D. P.; Guerreiro, M. V. (1986). Almanaques ou a Sabedoria e as Tarefas do Tempo. Revista ICALP, 6, 43-52.

Farias, P. L.; Aragão, I. R.; Cunha Lima, Edna L. O. da. (2012). Unraveling aspects of Brazilian design history through the study of 19 th century almanacs and type specimens. Conference Proceedings: Design Research Society 2012, 2.

Ferreira, Jerusa Pires. (2001). Almanaque. Do Almanak aos Almanaques. São Paulo: Ateliê Editorial.

Flusser, V. (2007). O mundo codificado: por uma filosofia do design e da comunicação. São Paulo: Cosac Naify.

Fonseca, L. P.; Gomes, D. D. and Campos, A. P. (2016). Conjunto Metodológico para Pesquisa em História do Design a partir de Materiais Impressos. Infodesign Revista Brasileira de Design da Informação, 13(2), 143-161.

Galvão, R. M. (2002). Os sucessores de Zacuto: o almanaque na Biblioteca Nacional do século XV ao XXI. Lisboa: Biblioteca Nacional.

Hallewell, L. (2005). O livro no Brasil. Sua história. São Paulo: Edusp.

Le Goff, Jacques. (1990). História e memória. Campinas: Unicamp. 
Lisboa, J. L. (2002). Almanaques. Os sucessores de Zacuto: o almanaque na Biblioteca Nacional do século XV ao XXI. Lisboa: Biblioteca Nacional.

Macambira, D. D. (2010). Impressões do tempo: Os Almanaques no Ceará (1870-1908) (Master's thesis). Universidade Federal do Ceará, Fortaleza.

Martins, F. O. (2017). Impresso no Pará: 1820-1919. A memória gráfica como composição do espírito de época (Doctoral dissertation). Universidade do Estado do Rio de Janeiro, Rio de Janeiro.

Mesquita, O (2006). Manaus, história e arquitetura (1852-1910). Manaus: Editora Valer.

Meyer, M. (org.). (2001). Do Almanak aos Almanaques. São Paulo: Ateliê Editorial.

Park, M. B. (1998). Histórias e leituras de almanaques no Brasil (Doctoral dissertation). Universidade Estadual de Campinas, Campinas.

Porta, F. (1958). Dicionário de artes gráficas. Porto Alegre: Editora O Globo.

Pereira, R. do N.; MEDEIROS, Ligia. (2016). Subsídios para uma história do design gráfico no Brasil: a primeira tipografia do Amazonas (1851-1866). Anais do $12^{\circ}$ Congresso Brasileiro de Pesquisa e Desenvolvimento em Design.

Santos, R. A. O. (1980). História econômica da Amazônia (1800-1920). São Paulo: T. A. Queiroz.

Souza, M. (2009). A História da Amazônia. Manaus: Editora Valer.

Trizotti, P. T (2008). Almanaques: história, contribuições e esquecimento. DIALOGUS, $4(1)$. 
